\title{
Hybrid Purity Test in Chilli (Capsicum annum L.) by Using SSR Marker
}

\author{
Jotshana Manik Maske*, Rajput Charansing Amarsing and Zote Rahul Keshavrao \\ Department of Plant Biotechnology SDMVM's College of Agricultural Biotechnology, \\ GeoraiTanda, Paithan Road, Aurangabad (M.S.)- 431001, India \\ *Corresponding author
}

\section{A B S T R A C T}

\begin{tabular}{|l|}
\hline Key w or d s \\
Hybrid, Chilli, SSR, \\
Marker \\
\hline Article Info \\
\hline $\begin{array}{l}\text { Accepted: } \\
\text { 20 April } 2018 \\
\text { Available Online: } \\
\text { 10 May } 2018\end{array}$ \\
\hline
\end{tabular}

Keywords

Hybrid, Chilli, SSR,

\section{Introduction}

Capsicum genus originated from tropical and humid zone of central and southern America and belongs to the Solanaceae family. Chilly is one of the most important commercial crops of India. It is grown almost throughout the country. There are more than 400 different varieties of chillies found all over the world. In Indian subcontinent, chillies are produced throughout the year. Two crops are produced in kharif and rabi seasons in country . Chilli grows best at $20^{\circ} \mathrm{c}-30^{\circ} \mathrm{c}$. Growth and yields suffer when temperatures exceed $30^{\circ} \mathrm{c}$ or drops below $15^{\circ} \mathrm{c}$ for extended periods. India is the world largest producer, consumer and exporter of Chilly peppers. Among which the city of
Guntur in Andhra Pradesh produces 30\% of all the Chillies produced in India, and the state of Andhra Pradesh contributes to $75 \%$ of all the chilly exports from India. Deoxyribonucleic acid (DNA) Polymorphism provides a powerful tool for quantifying the existing level of genetic variation in plant germplasm, either cereal or vegetable. Molecular marker can provide an effective tool for efficient selection of desired agronomic trait because they are based on the plant genotype and thus are independent of environment variation. Now a day, several molecular markers are developed, of which Simple Sequence repeats (SSR) or microsatellites are the most widely use types. Simple sequence repeats (SSR) are the most 
widely used marker system for plant variety characterization and diversity analysis especially in cultivated species which have low level of polymorphism.

Various marker techniques have been applied either individually or in combination to study the comparative study of various plant species. Among the wide variety of available marker system, Simple Sequence repeat (SSRs, also called microsatellite), which are short random repeat units of between 1 and $6 \mathrm{bp}$ in length (Tautz, 1989), offer a number of advantages which have made them increasingly popular in plant and animal studies. SSRs are highly polymorphic due to variation in repeat number and are co-dominantly inherited (Rafalski et al., 1996). Most SSRs are single - locus markers.

The presence of SSRs in the transcripts of genes suggests that they might have a role in gene expression or function; however, it remain to be whether any unusual phenotypic variation might be associated with the length of SSRs in coding region. Varshney et al., (2005) standardized the protocol for DNA isolation by CTAB method.

\section{Materials and Methods}

The present investigation entitled 'genetic/hybrid purity test in Capsicum annum spp. By SSR marker' was carried out at Department of Plant Biotechnology SDMVM's College of Agricultural Biotechnology, Georai Tanda, Paithan Road, Aurangabad (M.S.), 431001 during Jan. 2014 to May 2014.

The details of the material used and methods fallowed for the present investigation are given below. There was crossing between two hybrid variety i.e., DISHA x JALNA for hybrid purity testing of F1 generation.
Isolation of DNA by SDS method (Sodium dodacyle sulphate)

\section{Reagents}

Extraction buffer consist of following reagents (PH-8.0)

Tris $\mathrm{HCl} 100 \mathrm{mM} \quad-0.1 \mathrm{M}$

$\mathrm{NaCl} \quad 250 \mathrm{mM} \quad-0.25 \mathrm{M}$

EDTA $250 \mathrm{mM} \quad-0.05 \mathrm{M}$

Glucose $15 \% \quad-3.75 \mathrm{M}$

Ammonium acetate $-7.5 \mathrm{M}$

Suspension buffer $\quad-400 \mu 1$

Isopropanol - 2/3 drops

T E buffer (10mM Tris and 1mM EDTA, pH 8.0).

\section{Methodology for SSR marker analysis}

Genomic DNA was isolated from each of the parents and individual genotype of each of the backcross population using a modified CTAB method (Sharma et al., 2008).

\section{Sample collection for DNA extraction}

Fresh tissue leaf sample were collected from three weeks old seedling.

DNA was extracted from each of the parents and using cetyl trimethyl ammonium bromide (CTAB) method (Doyle and Doyle et al., 2001)

\section{PCR amplification}

\section{Preparation of reaction mixture for PCR}

The PCR was carried but in small reaction tubes containing a reaction volume typically of $25 \mu$ that was inserted into a PCR machine. For PCR reaction, master mix was prepared first. 


\section{Procedure for PCR reaction}

i) Sterile micro centrifugation tubes were numbered and placed on PCR tube stand.

ii) $2 \mu 1$ of DNA was added to each PCR tube fallowed by $19.99 \mu 1$ master mix.

iii) $1.5 \mu \mathrm{l}$ of each forward and reverse primers was added in each PCR tube.

iv) The samples were mixed by brief centrifugation to bring down the content to tube.

v) PCR was run on the programmable thermal cycler with the following programme.

\section{Results and Discussion}

To evaluating the hybrid purity for Disha $\mathrm{X}$ Jalwa.4 Polymorphic primer were tested. Primer I showed 100\% Heterozygocity (H) such as binding pattern looking like P1 and P2 primer II and III also showed 100\% hybrid purity. Primer IV showed 99\% hybrid purity.
Plant number 10 did not show any binding pattern so it was scored "O" (OFFLINE).

- Total 20 plants of hybrid were scored in the study total 87 marker data point generated. 4 primer were used for evaluating hybrid purity and showed $99 \%$ purity.

Genetic purity or genuiness of the cultivar is tested by means of heritable characters (morphological, physiological, or chemical) of fruits of chilly or plants. Morphological evaluation of fruits of chilli used for purity and variety distinctness is time consuming and expensive. This experiment set to evaluate the usefulness of SSR markers to determine genetic purity of commercial hybrids and their inbreed lines. There was crossing between 2 varieties of chilli of some crop and then hybrid variety of chilli was formed, By using some technique and some protocol for purity testing of chilli the hybrid purity was checked and their morphological characters were studied (Table 1-4 and Fig. 1).

Table. 2 Master mix for $1 \mathrm{X}$ of $25 \mu 1$ reaction

\begin{tabular}{|c|c|}
\hline MASTER MIX & $\mathbf{1 X}$ \\
\hline 10X Taq polymerase & $2.5 \mu 1$ \\
\hline $\operatorname{Mgcl}_{2}(25 \mathrm{mM})$ & $1.3 \mu 1$ \\
\hline dNTPs $(10 m M)$ & $0.27 \mu 1$ \\
\hline Taq polymerase $(15 \mathrm{U} / \mu \mathrm{I})$ & $0.10 \mu \mathrm{l}$ \\
\hline Sterile distilled water & $15.65 \mu 1$ \\
\hline \multicolumn{2}{|l|}{ PCR Reaction } \\
\hline Master mix volume & $20 \mu \mathrm{l}$ \\
\hline $\begin{array}{l}\text { Primer } \\
\text { 1.Riverse primer } \\
\text { 2.forward primer }\end{array}$ & $\begin{array}{l}1.3 \mu \mathrm{l} \\
1.3 \mu \mathrm{l}\end{array}$ \\
\hline Template DNA (30ng) & $6 \mu \mathrm{l}$ \\
\hline Total Reaction volume & $25 \mu \mathrm{l}$ \\
\hline
\end{tabular}


Table.1 List of SSR primer used with their sequence

\begin{tabular}{|l|l|l|l|l|}
\hline SR.NO. & $\begin{array}{l}\text { PRIMER } \\
\text { CODE }\end{array}$ & PRIMER SEQUENCE & $\begin{array}{l}\text { ANNEALING } \\
\text { TEMP }\end{array}$ & $\begin{array}{l}\text { PRODUCT } \\
\text { SIZE(bp) }\end{array}$ \\
\hline $\mathbf{1}$ & SSR1 & TGTATCCTGGTGGACCAATG & $57^{\circ} \mathrm{C}$ & $240-300$ \\
\hline $\mathbf{2}$ & SSR2 & TAGTGCAGCGGGATTAAGAG & $57^{\circ} \mathrm{C}$ & $280-350$ \\
\hline $\mathbf{3}$ & SSR3 & AATTCGGTGCACCGTTATCC & $57^{\circ} \mathrm{C}$ & $150-250$ \\
\hline $\mathbf{4}$ & SSR4 & GGGTTACCTTCAATAGACCC & $57^{\circ} \mathrm{C}$ & $170-250$ \\
\hline
\end{tabular}

Table.3 The score sheet indicating genotype status

\begin{tabular}{|l|l|l|l|l|}
\hline PLANT NO. & \multicolumn{3}{l|}{ PRIMER } \\
\cline { 2 - 4 } & SSR1 & SSR2 & SSR3 & SSR4 \\
\hline Plant no. 1 & H & H & H & H \\
\hline Plant no. 2 & H & H & H & H \\
\hline Plant no. 3 & H & H & H & H \\
\hline Plant no. 4 & H & H & H & H \\
\hline Plant no. 5 & H & H & H & H \\
\hline Plant no. 6 & H & H & H & H \\
\hline Plant no. 7 & H & H & H & H \\
\hline Plant no. 8 & H & H & H & H \\
\hline Plant no. 9 & H & H & H & H \\
\hline Plant no. 10 & H & H & H & O \\
\hline Plant no. 11 & H & H & H & H \\
\hline Plant no. 12 & H & H & H & H \\
\hline Plant no. 13 & H & H & H & H \\
\hline Plant no. 14 & H & H & H & H \\
\hline Plant no. 15 & H & H & H & H \\
\hline Plant no. 16 & H & H & H & H \\
\hline Plant no. 17 & H & H & H & H \\
\hline Plant no. 18 & H & H & H & H \\
\hline Plant no. 19 & H & H & H & H \\
\hline Plant no.20 & H & H & H & H \\
\hline
\end{tabular}

Table.4 Summer statistics of hybrid purity testing for DISHA x JALWA

\begin{tabular}{|l|l|l|}
\hline SR. NO. & Particular & Quantity \\
\hline 1. & No. of plants screened & 20 \\
\hline 2. & No. polymorphic band & 4 \\
\hline 3. & Scorable marker data & 87 \\
\hline 4. & Percentage of heterozygous & $99 \%$ \\
\hline
\end{tabular}


Fig.1 Banding pattern of DNA by SSR marker in chilli
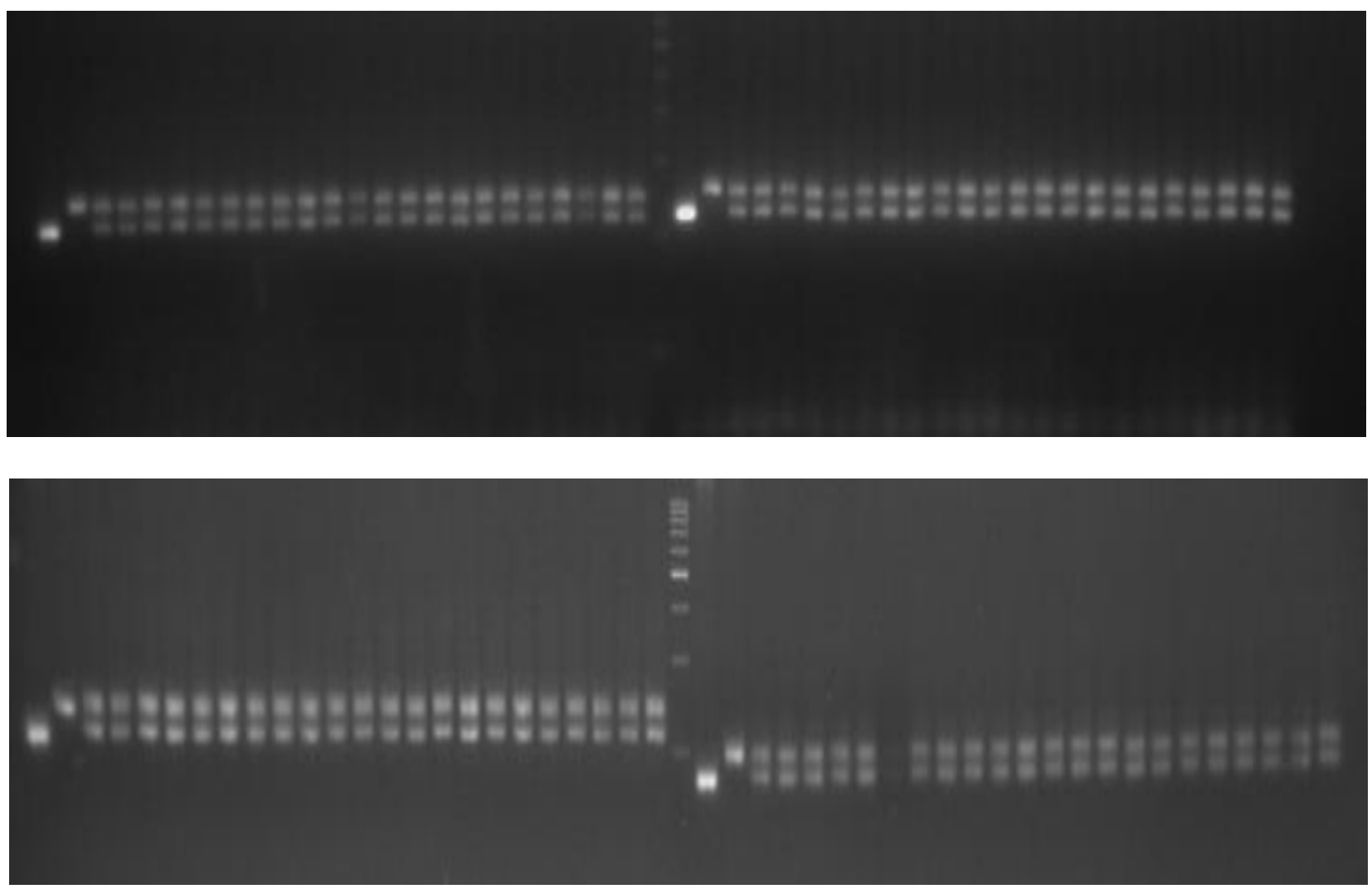

In conclusion, there was crossing between DISHA x JALWA. After crossing, total 20 plants of chilly variety tested hybrid purity. Only one hybrid plant was failure to show heterozygocity i.e., it was show the offline. This was outcome of the hybrid purity test in hybrid variety of chilly. Out of total 3extraction buffer only one is able to standardized the protocol of DNA isolation. Extraction buffer 3 shows the perfect bands of DNA.

\section{References}

Bonisetti and K (2012) identification of candidate gene based SSR marker for lysine and tryptophan metabolic pathway in maize (Zee mays).plant Breeding 131(I), 20-27.

Kalinka Carla Padovani de Cayvalho Salgado (2006), Genetic purity certificate in seeds of hybrid maize using molecular marker. Rev. Bras. Sementes, 28(1), Pelatas.

NACGRAB, (2004), Crop varieties released and registered in Nigeria. Publication of National Centre for Genetic Resources and Biotechnology MP lbadon, Nigeria.

Wa and M. (2010). Rapid and reliable purity identification of $\mathrm{F} 1$ hybrids of maize (Zea mays L.) using SSR markers. Plant Breeding, 4(3), 381-384.

Nandakumar and N., Singh, A.K., Sharma, R. K., Mohapatra, J., Prabhu, K.V., and Zaman, F. U. 2004. Molecular fingerprinting of hybrids assessment of genetic purity of hybrid seeds in rice using microsatellite markers. Euphytica, 136:257-264.

Sharma et al., 2008. Identification of informative SSSR markers capable of 
distinguishing hybrid rice parental lines and their utilization in seed purity element Euphytied 163:215224.

Varshney and A. Graner, M. G. Sorrells Trends in Biotechnology Genic microsatellite markers in plants features and application. R.K Rapid and reliable purity identification of $\mathrm{F} 1$ hybrid of maize (Zea mays L.) using SSR markers. 23(1), 48-55

Arus and P., Shields, C. R., Orton, T. J. (1985) Application of isoenzyme electrophoresis for purity testing and cultiver identification of $\mathrm{F} 1$ hybrids of Brassica oleraceae. Euphytica 34:pp.651-657.
Gupta, M., Chyi, Y. S., Romero-Severson, J., Owen, J. L. (1994) Amplification of DNA marker from evolutionary diverse genomics using single primers of SSR theory. Application Genet 89: pp.998-1006.

Livneh, O. Nagler. Y., Tal, Y., Gafni, S. B., Beckmann, J. S., Sela, J. (1990) RFLP analysis of a hybrid cultivar of pepper (Capsicum annum) and its use in distinguishing between parental lines and in hybrid identification. Seed Sci. and Technol., 18: 209-214.

Pavan, I., Horowitz, M., Zamir, D., Wolf, S. (1995). RAPD markers are useful for purity determination of tomato hybrids. Hort.Sci. 30: 377.

\section{How to cite this article:}

Jotshana Manik Maske, Rajput Charansing Amarsing and Zote Rahul Keshavrao. 2018. Hybrid Purity Test in Chilli (Capsicum annum L.) by Using SSR Marker. Int.J.Curr.Microbiol.App.Sci. 7(05): 2652-2657. doi: https://doi.org/10.20546/ijcmas.2018.705.307 